\author{
Nutritional influences on bone mass \\ BY DAVID M. REID ${ }^{1}$ AND SUSAN A. NEW ${ }^{2}$ \\ 'Osteoporosis Research Unit, Department of Medicine and Therapeutics, University of \\ Aberdeen, Aberdeen AB25 2ZD \\ ${ }^{2}$ Centre for Nutrition and Food Safety, School of Biological Sciences, University of Surrey, \\ Guildford GU2 5XH
}

\begin{abstract}
Bone is composed of an organic matrix of type I collagen associated with non-collagenous proteins and a large mineral component consisting of calcium hydroxyapatite. To date, measurement of bone mass only takes into account the mineral component of bone, while recognizing that the organic matrix is important in providing both structure and strength. The present paper will concentrate on the influence of nutrition on bone mass, examining initially the effects of bone mass with ageing, defining the principal disease of bone mass (i.e. osteoporosis), considering the genetic and environmental factors which affect bone mass and summarizing the methods of bone health assessment. The review will then focus on the nutritional factors (from both dietary sources and in the form of supplementation) which may influence bone mass and fracture rates. Finally, examination of how our knowledge of nutrition factors could be used to target lifestyle changes in individuals at risk of future osteoporosis will be discussed.
\end{abstract}

\title{
BONE MASS AND OSTEOPOROSIS
}

Bone mass in later life depends on the peak bone mass achieved during growth and the rate of subsequent age-related bone loss. Bone mass is gained throughout childhood and accelerates during the prepubertal growth spurt (Bonjour et al. 1991). From the age of 20 years until approximately 40 years, bone mass is stable in both sexes, with a linear rate of loss in men starting in the fifth decade but an accelerated rate of loss in women just after the menopause (Kroger et al. 1992). This accelerated rate of loss seen in women (which occurs especially at trabecular-rich sites such as the spine or wrist), when associated with a low attainment of peak bone mass, leads to excessive risk of future fracture.

The condition of osteoporosis has been defined as a systemic skeletal disease characterized by low bone mass and microarchitectural deterioration of bone tissue, with a consequent increase in bone fragility and susceptibility to fracture (Consensus Development Conference, 1993). The difficulty in using this definition in clinical practice has led to a Working Party of the World Health Organization redefining osteoporosis according to bone mass, at least for women. Osteoporosis has been defined as a bone mineral content or bone mineral density (BMD) more than 2.5 standard deviations below the young normal mean, and established osteoporosis as the same mass definition but associated with a fragility fracture (World Health Organization, 1994).

\section{GENETIC AND ENVIRONMENTAL INFLUENCES ON BONE MASS}

It is beyond the scope of the present article to review the pathogenesis of osteoporosis, but it is clear that predisposition to osteoporotic fracture is related first to peak bone mass and second to the rate of bone loss. Both peak bone mass and rates of loss are determined by a 
combination of genetic and environmental factors and recently these have been elegantly reviewed (Ralston, 1996). It is considered that up to $75 \%$ of the variation in bone mass in the elderly is influenced by genetic factors (Flicker et al. 1995), leaving a relatively limited role for environmental associates including nutrition. However, some genetic markers may influence the effectiveness of nutritional factors in controlling bone loss. This has been demonstrated in relation to the vitamin D-receptor polymorphisms which may influence Ca-related bone loss in the elderly (Ferrari et al. 1995).

\section{ASSESSMENT OF BONE MASS}

As osteoporosis has been defined according to the amount of bone present in the skeleton, it is important to have methods available for accurate and precise assessment. The most commonly used technique to date is dual-energy X-ray absorptiometry (DXA) which uses a tiny dose of X-rays (Miller et al. 1995). DXA can be used to define risk of future fracture, diagnose low bone mass or osteoporosis and assess the response to treatment for the disease.

The last decade has seen the development of a new and exciting technique known as broadband ultrasound attenuation (BUA). The method has great potential since it is relatively inexpensive, highly portable and uses no harmful radiation (Heaney \& Kanis, 1996). It can be used to predict elderly patients at risk of hip fractures, but does not measure BMD directly and, therefore, cannot be used at present to define osteoporosis. There are persisting claims that it may measure structural components which are not assessed by DXA (Njeh et al. 1997), but further research is required.

In assessing the nutritional influences on bone mass it is particularly pertinent to know that bone mineral 'density' corrects for projected bone area and, therefore, is not a true density measurement. Many studies have demonstrated that this 'areal' BMD does not adequately correct for the influences of body size and some studies have indicated that BMD remains significantly correlated with projected bone area (Prentice et al. 1994). Although methods have been described to estimate volumetric bone density, there seems no major advantage to this technique in terms of the discriminatory value of bone mass in patients with fractures or in precision measurements (Mazess et al. 1994).

\section{NUTRITIONAL INFLUENCES ON BONE MASS}

A large number of macro- and micronutrients have been considered to have some effect on bone health. It is not possible to cover all these nutrients in the following review and, thus, attention will be focused on $\mathrm{Ca}$, protein, fibre, $\mathrm{K}$ and trace elements.

\section{Calcium}

Since $\mathrm{Ca}$ is the most important mineral constituent of the skeleton, its role in the regulation of bone mass has been the centre of much controversy (Kanis \& Passmore, 1989a,b; Nordin \& Heaney, 1990). However, in a meta-analysis of all studies up to 1988 relating Ca intake and bone status, it was concluded that the evidence supported a positive relationship between the two variables (Cummings, 1990). 
The association between $\mathrm{Ca}$ and bone health will be reviewed as follows: (1) Ca intake during skeletal growth; (2) Ca intake in the premenopausal years; (3) relationship of $\mathrm{Ca}$ intake to bone loss (early and late post-menopausal); (4) intake of $\mathrm{Ca}$ and risk of fracture.

Calcium intake during skeletal growth. Studies at the beginning of the century showed that children who consumed milk grew taller compared with subjects without milk supplementation (Orr, 1928; Leighton \& Clark, 1929). Although BMD assessment was not available at that time, there is now accumulating evidence for the benefits of $\mathrm{Ca}$ intake on bone mass during childhood (Lee et al. 1993), adolescence (Matkovic et al. 1990) and early adulthood in British (Fehily et al. 1992), Finnish (Valimaki et al. 1994), Chinese (Ho et al. 1994) and American women (Kanders et al. 1988; Recker et al. 1988). There are also data to show that a high past intake of milk is beneficial to bone health in premenopausal (New et al. 1997), post-menopausal (Sandler et al. 1985) and elderly women (Murphy et al. 1994).

Ca supplementation has been shown also to positively influence bone mass during skeletal growth in both children (Johnston et al. 1992) and young girls (Lloyd et al. 1993), and a similar effect has been reported with milk supplementation in British adolescents (Cadogan et al. 1995). In the 3-year study of identical twins by Johnston et al. (1992), skeletal density increased in children receiving Ca supplements of $700 \mathrm{mg} / \mathrm{d}$ in addition to their normal diets. However, in a follow-up of these subjects 2 years later, the effect of $\mathrm{Ca}$ intake had all but disappeared, raising the question of whether the effect is ephemeral (Slemenda et al. 1993).

There is increasing evidence to suggest that $\mathrm{Ca}$ is a threshold nutrient. While sufficient exogenous Ca must be present to sustain density during growth and maintain skeletal mass in later life, additional $\mathrm{Ca}$ above the threshold may not necessarily produce more bone gain than that which is predestined by both genetic predisposition and levels of mechanical loading (Matkovic, 1991). Analysis of $487 \mathrm{Ca}$ balance studies indicated the presence of a balance threshold at all stages of growth, from infancy up through the skeletal consolidation years (Matkovic \& Heaney, 1992). The threshold values were found to be $1400 \mathrm{mg} / \mathrm{d}$ in children aged 2-8 years, $1480 \mathrm{mg} / \mathrm{d}$ in adolescents aged 9-17 years and $960 \mathrm{mg} / \mathrm{d}$ in young adults aged $18-30$ years. These values are higher than the recommended dietary allowance (RDA; National Research Council, 1989) and dietary reference values (DRV; Department of Health, 1991) for the ages concerned both in the USA and UK. A recent Canadian review has also led to the conclusion that recommended dietary intakes of $\mathrm{Ca}$ are too low (Murray, 1996).

Calcium intake in the premenopausal years. Only two studies have shown Ca supplementation to be of benefit in premenopausal women. Baran et al. (1990) found no bone loss in women supplemented with dairy products, compared with increased loss in the unsupplemented group. However, the difference was detectable in the 3rd year, at which time there was a $37 \%$ withdrawal rate. More recently, Rico et al. (1994) found a positive effect of supplementation of calcium pidolate on bone mass.

There have been a number of studies examining the relationship between dietary $\mathrm{Ca}$ intake and bone mass in premenopausal women. Although some have reported a significant association between $\mathrm{Ca}$ intake and BMD in premenopausal women, including studies in European (Matkovic et al. 1979), British (Ramsdale et al. 1994), and Chinese women (Hu et al. 1993), other groups, including our own, have found there to be no relationship (McCulloch et al. 1990; Valimaki et al. 1994; New et al. 1997).

There are several reasons which may help to explain this apparent discrepancy. Those studies which report a positive relationship between $\mathrm{Ca}$ intake and bone mass fail to 
comment on the fact that in subjects with higher $\mathrm{Ca}$ intakes, energy intakes were also higher and yet body weight was not significantly different, thus suggesting increased physical activity. Furthermore, dietary intake has often been assessed using a method which is unreliable and unrepresentative of habitual food intake. This unreliability is confirmed by reported energy intakes which are extremely low $(<1.2 \times \mathrm{BMR})$, indicating the likelihood of under-reporting and, thus, potentially biased data.

Relationship between calcium intake and bone loss. Virtually all published studies show little or no effect of dietary or supplementary $\mathrm{Ca}$ during the 5 years following the menopause (Ettinger et al. 1987; Riggs et al. 1987; Riis et al. 1987; Stevenson et al. 1988; Dawson-Hughes et al. 1990). Elders et al. (1991) showed that supplementation with 1000 and $2000 \mathrm{mg}$ elemental $\mathrm{Ca} / \mathrm{d}$ retarded bone loss in the first year of supplementation, but not in the second year. In the study by Dawson-Hughes et al. (1990) women who were less than 5 years post-menopause, had rapid bone loss not affected by Ca supplementation $(500 \mathrm{mg} / \mathrm{d})$. However, in women who had been post-menopausal for 6 years or more, with a daily intake of Ca of less than $400 \mathrm{mg} / \mathrm{d}$, bone loss was significantly reduced. High-dose supplementation $(1000 \mathrm{mg} / \mathrm{d})$ may have a benefit on total and site-specific bone mass in those 10 years from the menopause, even when dietary intake of $\mathrm{Ca}$ is satisfactory (Reid et al. 1993). This supplementation effect may last for as long as 4 years and result in fewer fractures, although bone loss is not entirely prevented (Reid et al. 1995). Positive influences of dietary Ca on bone density (Andon et al. 1991) and supplementary Ca on bone loss (Smith et al. 1989; Nelson et al. 1991; Prince et al. 1991) have also been reported in other groups of older women.

Intake of calcium and risk of fracture. The study by Matkovic et al. (1979) was the first to demonstrate anti-fracture efficacy for high-Ca diets, with a reduction in risk at the hip, but not at the wrist. Several epidemiological studies have since been reported with conflicting results. Holbrook et al. (1988) in a 14-year longitudinal study found that hip fracture rates were lower in individuals ingesting high-Ca diets and similar findings were reported in the Hong Kong population (Lau et al. 1988). In the UK, Cooper et al. (1988) compared physical activity and $\mathrm{Ca}$ intakes of 300 elderly men and women who had sustained hip fractures with 600 age- and sex-matched controls. Ca intake was not related to the risk of fracture in women, but men with an intake greater than $1000 \mathrm{mg} / \mathrm{d}$ had lower risks. In a further UK study, Wickham et al. (1989) also found no evidence for a relationship between $\mathrm{Ca}$ intake and risk of hip fracture.

Using fracture itself as the end point, Chapuy et al. (1992) in a large and wellcontrolled study, showed substantial reductions in fracture rates in a large group of institutionalized elderly given supplements of $\mathrm{Ca}$ and cholecalciferol. Protection became apparent after 6-12 months of treatment, and by 18 months, fractures were reduced by more than $30 \%$ in the treated individuals. Similar results were found when an annual injection of cholecalciferol was given (Heikinheimo et al. 1992), but no differences were seen with cholecalciferol without $\mathrm{Ca}$ (Lips et al. 1996). In the most recent study, Ca supplementation in vitamin D-replete elderly subjects was found to reduce fracture rates (Chevalley et al. 1994).

In summary, while differences in the findings of studies remain, there is some agreement that $\mathrm{Ca}$ intake (and indeed supplementation) is beneficial during peak bone mass development, and has some effect at slowing bone loss in late post-menopausal women, (particularly if $\mathrm{Ca}$ intakes are low). There is also growing evidence that it may even help prevent hip fracture. 


\section{Protein}

Increased protein intake has been associated with an increase in urinary Ca excretion, thus shifting $\mathrm{Ca}$ balance in a negative direction. With protein intakes below $175 \mathrm{~g} / \mathrm{d}$, the relationship between dietary protein and urinary $\mathrm{Ca}$ has been shown to be linear, such that for each $50 \mathrm{~g}$ increment of protein consumed, an extra $60 \mathrm{mg}$ urinary $\mathrm{Ca}$ is lost (Kersetter \& Allen, 1989).

The decrease in $\mathrm{Ca}$ absorption which occurs with increased protein intake is related to the acid generated from protein metabolism. Oxidation of the $S$ amino acids, methionine and cysteine, yields inorganic sulfate and two $\mathrm{H}$ ions. Metabolic acidosis is associated with elevated urinary $\mathrm{Ca}$, and the addition of a base reduces urinary $\mathrm{Ca}$ losses. Approximately half the urinary $\mathrm{Ca}$ can be attributed to the $\mathrm{S}$ amino acids and acid load, and the elevated glomerular filtration rate immediately following a high-protein meal is likely to contribute to the other half. It has been shown that serum bicarbonate remains normal during $\mathrm{H}$ ion retention, and thus in order to respond to the acid load imposed by protein intake, it is possible that bone is buffered to maintain the acid-base balance (Lutz, 1984).

Thus, populations which consistently consume high levels of animal protein, should, in theory at least, have a higher prevalence of low-BMD and osteoporotic-related fractures, and increased bone resorption. Hegsted (1986) noted high protein intakes were associated with a higher incidence of hip fractures across several nations, and in a recent metaanalysis of thirty-four publications in sixteen countries, a strong positive association existed between animal protein intake and age-adjusted female fracture rates (Abelow, 1992). However, the results of studies comparing omnivorous diets with lacto-vegetarian diets are conflicting. Some researchers have found high bone density in vegetarian women consuming less protein (Marsh et al. 1980, 1988), while others have concluded differently (Tylavsky \& Anderson, 1988; Hunt et al. 1989; Tesar et al. 1992). In a recent study, no differences were found in rate of bone loss between elderly lacto-ovo-vegetarians and omnivores (Reed et al. 1994). Furthermore, a recent population-based study indicated that dietary intake of protein was positively correlated with bone mass at the lumbar spine, hip and radius, although these associations were reduced after age adjustment and were only present in premenopausal women (Cooper et al. 1996).

The effect of dietary protein insufficiency on bone health has received much less attention, but there is some evidence to show that hip-fracture patients are deficient in protein and energy (Mitchell \& Lipschitz, 1982) and may benefit from supplementation (Delmi et al. 1990).

In summary, while it is clear that high protein intakes affect $\mathrm{Ca}$ balance and possibly acid-base status, long-term influences of high intakes of protein, outside the experimental setting, have yet to prove substantially that excess protein intake is detrimental to bone health.

\section{Fibre}

Increased fibre intake (using wheat bran as the fibre source) has been associated with a decrease in $\mathrm{Ca}$ absorption, which can be summarized as a decrease in absorption of about 20-30\% when going from an intake of 0.1 to approximately $30 \mathrm{~g}$ bran fibre/d (Heaney $e t$ al. 1991). Fibre intake has also been associated with increased urinary $\mathrm{Ca}$ excretion and lower oestradiol levels in pre- and post-menopausal women (Barbosa et al. 1990; Feng et al. 1993). This reduction in hormone levels may be due to the interruption in the enterohepatic circulation of sex hormones. Such findings, for both reduced $\mathrm{Ca}$ absorption and 
decreased oestradiol levels has led to the assumption that increased intakes of fibre may have a negative effect on bone mass.

There is very little evidence for such an effect. Negative correlations between trabecular bone density (Leuenberger" et al. 1989) and fibre intake have been reported, while others have found no association (Yano et al. 1985). Increased bone loss with high fibre intake has been reported by our group, but only in diets which are weight reducing (Avenell et al. 1994).

The long-term lowering effects of high-fibre diets on circulating oestradiol levels and bone health has not yet been established. However, high $\mathrm{Ca}$ absorption from whole-wheat bread has been reported, similar to that measured for milk containing a comparable $\mathrm{Ca}$ load (Heaney et al. 1991). Good absorption for $\mathrm{Ca}$ has also been obtained from low-phytate foods such as kale (Brassica oleracea acephala) and soyabeans, (which contain large amounts of fibre) compared with a low $\mathrm{Ca}$ absorption from vegetables high in oxalate such as spinach (Spinacia oleracea; Heaney et al. 1988; Heaney \& Weaver, 1990). Wisker et al. (1991) found that large additions of low-phytate barley-fibre concentrate did not interfere with $\mathrm{Ca}$ absorption in normal adults. The high-fibre diet associations with reduced oestradiol levels have also only been found with wheat-bran fibre. Thus, the effect on $\mathrm{Ca}$ absorption may be due to phytate (which is present in substantial amounts in wheat bran), rather than the fibre intake per se (C. M. Weaver, personal communication). High fibre intakes from a mixed diet, therefore, may not be detrimental to bone health, which may help to explain the positive relationship seen between spine BMD and fibre intake in our own epidemiological study (New et al. 1997).

\section{Potassium}

$\mathrm{K}$ deserves special consideration as there is growing evidence for beneficial effects of $\mathrm{KHCO}_{3}$ on mineral balance and skeletal metabolism. As noted by Wachman \& Bernstein (1968), the skeleton is not only a labile reservoir of $\mathrm{Ca}$ responsive to the mechanisms which maintain ionic $\mathrm{Ca}$, but it also contains a reservoir of alkaline salts of $\mathrm{Ca}$ which, in turn, provide a source of labile base. This can be mobilized to react to both blood $\mathrm{pH}$ and plasma bicarbonate concentrations. The failure to maintain adequate acid-base homeostasis in adults has been proposed as the main reason for the progressive decline in bone mass which occurs with age (Wachman \& Bernstein, 1968), excepting of course the rapid immediately post-menopausal loss mediated by oestrogen lack. Such bone loss may be due to the lifelong mobilization of skeletal calcium salts to balance the endogenous acid generated from foods such as meat.

$\mathrm{KHCO}_{3}$ has been shown to reduce urinary $\mathrm{Ca}$ excretion and improve $\mathrm{Ca}$ balance in healthy young adults (Lemann et al. 1991) and has also been shown to reduce bone resorption and increase the rate of bone formation in post-menopausal women (Sebastian $e t$ al. 1994). More recently, positive associations have been reported between dietary intakes of K and bone mass both by our group (New et al. 1997, 1998) and others (Michaelsson et al. 1995), and its role in bone health certainly warrants further attention.

\section{Trace elements}

$\mathrm{Zn}, \mathrm{Cu}$ and $\mathrm{Mn}$ are known to be essential metallic cofactors for enzymes involved in the synthesis of various bone matrix constituents, but their role in bone health is unclear. Positive associations between dietary intake of $\mathrm{Zn}$ and bone mass have been reported in women (Freudenheim et al. 1986; Angus et al. 1988), and work by Strause et al. (1994) has 
shown that bone loss in Ca-supplemented older post-menopausal women can be further arrested by concomitant increases in trace mineral intake. Furthermore, these trace elements (and vitamin C) may also function in their antioxidant capacity and, thus, high intakes may be important if the connective tissue of bone is a target for free-radical damage. This is an area which has received relatively little attention in the literature and warrants further study.

Awareness of the possible importance of $\mathrm{Mg}$ to bone health is also increasing. Several studies have noted a positive relationship between $\mathrm{Mg}$ intake and bone density. Cancellous bone of osteoporotic women has been shown to have a reduced $\mathrm{Mg}$ content compared with healthy bone from age-matched controls (Manicourt et al. 1981). Although Mg deficiency in animals causes increased bone resorption, its role in human bone metabolism is unclear and further studies are required to establish the optimal $\mathrm{Mg}$ vehicle, dosage and duration of treatment.

\section{PREVENTION OF OSTEOPOROSIS BY LIFESTYLE ADVICE}

The options for using the information on the relationship between bone mass, fracture risk and nutritional factors are to use these to influence lifestyle changes in the entire population or to target preventative therapy in those at most risk of fracture. Prevention might be possible by increasing dietary $\mathrm{Ca}$, vitamin $\mathrm{D}$ and possibly $\mathrm{K}, \mathrm{Mg}$ and vitamin $\mathrm{K}$. These dietary changes would almost certainly have to be associated with a general increase in weight-bearing exercise.

There are likely to be considerable costs in encouraging patients to take this lifestyle advice. In a randomized controlled trial of screening for osteoporosis, our own group were able to improve uptake of hormone-replacement therapy in those at risk of osteoporosis but were unable to affect the numbers of smokers or the exercise taken by those found to have low bone mass (Torgerson et al. 1997). It seems likely, therefore, that considerable effort would require to be expended on persuading women to alter their lifestyle, even when selected by the finding of a major risk factor, such as the presence of a genetic marker, presence of environmental risk factors including nutrition or low bone mass. Targeting of lifestyle advice may also be age-specific and may be particularly relevant in childhood and the elderly.

\section{CONCLUDING REMARKS}

If dietary manipulation is to be used as a preventative strategy, substantial reinforcement will be required and the costs of achieving such changes in the nation's diet will not be negligible. Targeting of advice, therefore, is likely to be necessary and primary intervention research is required to prove this hypothesis.

\section{REFERENCES}

Abelow, B. J., Holford, T. R. \& Insogna, K. (1992). Cross-cultural association between dietary animal protein and hip fracture: a hypothesis. Calcified Tissue International 50, 14-18.

Andon, M. B., Smith, K. T., Bracker, M., Sartoris, D., Saltman, P. \& Strause, L. (1991). Spinal bone density and calcium intake in healthy postmenopausal women. American Journal of Clinical Nutrition 54, 927-929.

Angus, R. M., Sambrook, P. N., Pocock, N. A. \& Eisman, J. A. (1988). Dietary intake and bone mineral density. Bone and Mineral 4, 265-277.

Avenell, A., Richmond, P. R., Lean, M. E. J. \& Reid, D. M. (1994). Bone loss associated with a high fibre reduction diet in postmenopausal women. European Journal of Clinical Nutrition 48, 561-566. 
Baran, D., Sorenson, A., Grimes, J., Lew, R., Karellas, A., Johrison, B. \& Roche, J. (1990). Dietary modification with dairy products for preventing vertebral bone loss in premenopausal women: a three year prospective study. Journal of Clinical and Endocrinology Metabolism 70, 264-270.

Barbosa, J. C., Schultz, T. D., Filley, S. J. \& Nieman, D. C. (1990). The relationship among adiposity, diet and hormone concentrations in vegetarian and nonvegetarian postmenopausal women. American Journal of Clinical Nutrition 51, 798-803.

Bonjour, J. P., Theintz, G., Buchs, B., Losman, D. \& Rizzoli, R. (1991). Critical years and stages of puberty for bone and femoral bone mass accumulation during adolescence. Journal of Endocrinology and Metabolism 73, 55-63.

Cadogan, J., Eastell, R., Jones, N. \& Barker, M. (1995). A study of bone growth in adolescents: the effect of an 18-month, milk-based dietary intervention. Proceedings of the Nutrition Society 55, $11 \mathrm{~A}$.

Chapuy, M. C., Arlot, M. E., Duboeuf, F., Brun, J., Crouzet, B., Arnaud, S., Delmas, P. D. \& Meunier, P. J. (1992). Vitamin D and calcium to prevent hip fractures in elderly women. New England Journal of Medicine 327, 1637-1642.

Chevalley, T., Rizzoli, R., Nydegger, V., Slosman, D., Rapin, C. H., Vasey, J. P. M., Vasey, H. \& Bonjour, J. P. (1994). The effects of calcium supplements on femoral bone mineral density and vertebral fracture rate in vitamin D-replete elderly patients. Osteoporosis International 4, 245-252.

Consensus Development Conference (1993). Diagnosis, prophylaxis and treatment of osteoporosis. American Journal of Medicine 94, 646-650.

Cooper, C., Atkinson, E. J., Hensrud, D. D., Wahner, H. W., O'Fallon, W. M., Riggs, B. L. \& Melton, L. J. (1996). Dietary protein intake and bone mass in women. Calcified Tissue International 58, 320-325.

Cooper, C., Barker, D. J. P. \& Wickham, C. (1988). Physical activity, muscle strength and calcium intake in fracture of the proximal femur in Britain. British Medical Journal 297, 1443-1446.

Cummings, R. G. (1990). Calcium intake and bone mass: a quantitative review of the evidence. Calcified Tissue International 47, 194-201.

Dawson-Hughes, B., Ballal, G.E., Krall, E. A., Sadowski, L., Sahyoun, N. \& Tannenbaum, S. (1990). A controlled trial of the effect of calcium supplementation on bone density in post-menopausal women. New England Journal of Medicine 323, 878-883.

Delmi, M., Rapin, C. H., Bengoa, J. M., Delmas, P. D., Vasey, H. \& Bonjour, J. P. (1990). Dietary supplementation in elderly patients with fractured neck of femur. Lancet 335, 1013-1016.

Department of Health (1991). Dietary Reference Values for Food, Energy and Nutrients in the UK. Report on Health and Social Subjects no. 41. London: H.M. Stationery Office.

Elders, P. J., Netelenbos, J. C., Lips, P., van Ginkel, F. C., Khoe, E., Leeuwenkamp, O. R., Hackeng, N. H. L. \& van der Stelt, P. F. (1991). Calcium supplementation reduces vertebral bone loss in perimenopausal women: a controlled trial in 248 women between 46 and 55 years of age. Journal of Clinical and Endocrinology Metabolism 73, 533-540.

Ettinger, B., Genant, H. K. \& Cann, C. E. (1987). Postmenopausal bone loss is prevented by treatment with lowdosage oestrogen with calcium. Annals of Internal Medicine 106, 40-45.

Fehily, A. M., Coles, R. J., Evans, W. D. \& Elwood, P. C. (1992). Factors affecting bone density in young adults. American Journal of Clinical Nutrition 56, 579-586.

Feng, W., Marshall, R., Lewis-Barned, N. J. \& Goulding, A. (1993). Low follicular oestrogen levels in New Zealand women consuming high fibre diets: a risk factor for osteopenia? New Zealand Medical Journal 106, $419-422$.

Ferrari, S., Rizzoli, R., Chevalley, T., Slosman, D., Eisman, J. A. \& Bonjour, J. P. (1995). Vitamin-D-receptorgene polymorphisms and change in lumbar-spine bone mineral density. Lancet $345,4$.

Flicker, L., Hopper, J. L., Rodgers, L., Kaymakci, B., Green, R. W. \& Wark, J. D. (1995). Bone density in elderly women: a twin study. Journal of Bone and Mineral Research 10, 1607-1613.

Freudenheim, J. L., Johnson, N. E. \& Smith, E. L. (1986). Relationship between usual nutrient intake and bone mineral content of women 35-65 years of age: longitudinal and cross-sectional analysis. American Joumal of Clinical Nutrition 44, 863-876.

Heaney, R. P. \& Kanis, J. A. (1996). The interpretation and utility of ultrasound measurements of bone. Bone 18, $491-492$.

Heaney, R. P. \& Weaver, C. M. (1990). Calcium absorption from kale. American Journal of Clinical Nutrition 51, 656-657.

Heaney, R. P., Weaver, C. M. \& Fitzsimmons; M. L. (1991). Soybean phytate content: effect on calcium absorption. American Journal of Clinical Nutrition 53, 741-744.

Heaney, R. P., Weaver, C. M. \& Recker, R. R. (1988), Calcium absorptability from spinach. American Journal of Clinical Nutrition 47, 707-709.

Hegsted, M. (1986). Calcium and osteoporosis. Journal of Nutrition 116, 2316-2319.

Heikinheimo, R. J., Inkovaara, J. A., Harju, E. J., Haavisto, M. V., Kaarela, R. H., Kataja, J. M., Kokko, A. M., Kolho, L. A. \& Rajala, S. A. (1992). Annual injection of vitamin D and fractures of aged bones. Calcified Tissue International 51, 105-110. 
Ho, S. C., Leung, P. C., Swaminathan, R., Chan, C., Chan, S. S. G., Fan, Y. K. \& Lindsay, R. (1994). Determinants of bone mass in Chinese women aged $21-40$ years. II. Patterns of dietary calcium intake and association with bone mineral density. Osteoporosis International 4, 167-175.

Holbrook, T. L., Barrett-Connor, E. \& Windgard, D. L. (1988). Dietary calcium and risk of hip fracture: 14 year prospective population study. Lancet, ii, 1046-1049.

Hu, J. F., Zhao, X. H., Jia, J. B., Parpia, B. \& Campbell, T. C. (1993). Dietary calcium and bone density among middle age and elderly women in China. American Journal of Clinical Nutrition 58, 219-227.

Hunt, I. F., Murphy, N. J., Henderson, C., Clark, V. A., Jacobs, R. M., Johnston, P. K. \& Coulson, A. H. (1989). Bone mineral content in postmenopausal women: comparison of omnivores and vegetarians. American Journal of Clinical Nutrition 50, 517-523.

Johnston, C. C., Miller, J. Z., Slemenda, C. W., Reister, T. K., Hui, S., Christian, J. C. \& Peacock, M. (1992). Calcium supplementation and increases in bone mineral density in children. New England Journal of Medicine 327, 82-87.

Kanders, B., Dempster, D. W. \& Lindsay, R. (1988). Interaction of calcium nutrition and physical activity on bone mass in young women. Journal of Bone and Mineral Research 3, 145-149.

Kanis, J. A. \& Passmore, R. (1989a). Calcium supplementation of the diet I. British Medical Journal 298, 137140 .

Kanis, J. A. \& Passmore, R. (1989b). Calcium supplementation of the diet II. British Medical Journal 298, 204 208.

Kersetter, J. E. \& Allen, L. H. (1989). Dietary protein increases urinary calcium. American Institute of Nutrition 120, 134-136.

Kroger, H., Heinkkinen, J., Liatinen, J. \& Kotaniemi, A. (1992). Dual energy x-ray absorptiometry in normal women. A cross-sectional study of 715 Finnish volunteers. Osteoporosis International 2, 135-140.

Lau, E., Donnan, S., Barker, D. J. P. \& Cooper, C. (1988). Physical activity and calcium intake in fracture of the proximal femur in Hong Kong. British Medical Journal 297, 1441-1443.

Lee, W. T. K., Leung, S. S. F., Lui, S. S. H. \& Lau, J. (1993). Relationship between long-term calcium intake and bone mineral content of children aged from birth to 5 years. British Journal of Nutrition 70, 235-248.

Leighton, G. \& Clark, M. L. (1929). Milk consumption and growth of school children; second preliminary report on tests to the Scottish Board of Health. Lancet ii, 40-43.

Lemann, J. Jr, Pluess, J. A., Gray, R. W. \& Hoffmann, R. G. (1991). Potassium administration reduces and potassium deprivation increases urinary calcium excretion in healthy adults. Kidney International 39, 973 983.

Leuenberger, P. K., Buchanan, J. R., Myers, C. A., Lloyd, T. \& Demers, L. M. (1989). Determination of peak trabecular bone density: interplay of dietary fiber, carbohydrate and androgens. American Journal of Clinical Nutrition 50, 955-961.

Lips, P., Graafmans, W. C., Ooms, M. E., Bezemer, P. D. \& Bouter, L. M. (1996). Vitamin D supplementation and fracture incidence in elderly persons - a randomized placebo-controlled clinical trial. Annals of Internal Medicine 124, 400-406.

Lloyd, T., Andon, M. B., Rollings, N., Martel, J. K., Landis, J. R., Demers, L. M., Eggli, D. F., Kieselhorst, K. \& Kulin, H. E. (1993). Calcium supplementation and bone mineral density in adolescent girls. Journal of the American Medical Association 270, 841-844.

Lutz, J. (1984). Calcium balance and acid-base status of women as affected by increased protein intake and by sodium bicarbonate ingestion. American Journal of Clinical Nutrition 39, 281-288.

McCulloch, R. G., Bailey, D. A., Houston, C. S. \& Dodd, B. L. (1990). Effects of physical activity, dietary calcium intake and selected lifestyle factors on bone density in young women. Canadian Medical Association Journal 142, 221-227.

Manicourt, D. H., Orloff, S., Brauman, J. \& Schoutens, A. (1981). Bone mineral content of the radius: good correlations with physiochemical determinations in iliac crest trabecular bone of normal and osteoporotic subjects. Metabolism 30, 57-62.

Marsh, A. G., Sanchez, T. V., Mickelson, O., Chaffee, F. L. \& Fagal, S. M. (1988). Vegetarian lifestyle and bone mineral density. American Journal of Clinical Nutrition 48, 837-841.

Marsh, A. G., Sanchez, T. V., Mickelsen, O., Keiser, J. \& Mayor, G. (1980). Cortical bone density of adult lactoovo-vegetarian and omnivorous women. Journal of the American Dietetic Association 76, 148-154.

Matkovic, V. (1991). Calcium metabolism and calcium requirements during skeletal modelling and consolidation of bone mass. American Journal of Clinical Nutrition 54, 245S-259S.

Matkovic, V., Fontano, D., Tominac, C., Goel, P. \& Chesnut, C. H. III (1990). Factors that influence peak bone mass formation: a study of calcium balance and the inheritance of bone mass in adolescent females. American Journal of Clinical Nutrition 52, 878-888.

Matkovic, V. \& Heaney, R. P. (1992). Calcium balance during human growth: evidence for threshold behaviour. American Journal of Clinical Nutrition 55, 992-996.

Matkovic, V., Kostial, K., Simonovic, I., Buzina, R., Brodarec, A. \& Nordin, B. E. C. (1979). Bone status and fracture rates in two regions of Yugoslavia. American Journal of Clinical Nutrition 32, 540-549. 
Mazess, R. B., Barden, H., Mautalen, C. \& Vega, E. (1994). Normalisation of spine densitometry. Journal of Bone and Mineral Research 9, 137-145.

Michaelsson, K., Holmberg, L., Maunin, H., Wolk, A., Bergstrom, R. \& Ljunghall, S. (1995). Diet, bone mass and osteocalcium. A cross-sectional study. Calcified Tissue International 57, 86-93.

Miller, P. D., Bonnick, S. L. \& Rosen, C. (1995). Guidelines for the clinical utilisation of bone mass measurement in the adult population. Calcified Tissue International 57, 51-52.

Mitchell, C. O. \& Lipschitz, D. A. (1982). Detection of protein-calorie malnutrition in the elderly. American Joumal of Clinical Nutrition 35, 398-406.

Murphy, S., Khaw, K. T., May, H. \& Compston, J. E. (1994). Milk consumption and bone mineral density in middle aged and elderly women. British Medical Journal 308, 939-941.

Murray, T. M. (1996). Prevention and management of osteoporosis: consensus statements from the Scientific Advisory Board of the Osteoporosis Society of Canada. 4. Calcium nutrition and osteoporosis. Canadian Medical Association Joumal 155, 935-939.

National Research Council (1989). Recommended Dietary Allowances, 10th ed. Washington, DC: National Academy Press.

Njeh, C. F., Boivin, C. M. \& Langton, C. M. (1997). The role of ultrasound in the assessment of osteoporosis: a review. Osteoporosis International 7, 7-22.

Nelson, M. E., Fisher, E. C., Avraham Dilmanian, F. A., Dallal, G. E. \& Evans, W. J. (1991). A 1-yr walking program and increased dietary calcium in postmenopausal women: effects on bone. American Journal of Clinical Nutrition 53, 1304-1311.

New, S. A., Bolton-Smith, C., Grubb, D. A. \& Reid, D. M. (1997). Nutritional influences on bone mineral density: A cross-sectional study in pre-menopausal women. American Journal of Clinical Nutrition 65, 18311839.

New, S. A., Tredger, J. A., Smith, R., Greenacre, M. C., Grubb, D. A. \& Reid, D. M. (1998). Association between present dietary intake and bone health in postmenopausal and elderly Scottish women. Proceedings of the Nutrition Society 57 (In the Press).

Nordin, B. E. C. \& Heaney, R. B. (1990). Calcium supplementation of the diet: Justified by present evidence. British Medical Journal 300, 1056-1060.

Orr, J. B. (1928). Milk consumption and the growth of school children. Lancet i, 202-203.

Prentice, A., Parsons, T. J. \& Cole, T. J. (1994). Uncritical use of BMD in absorptiometry may lead to size related artifacts in the identification of bone mineral determinants. American Jourmal of Clinical Nutrition 60 , 837-842.

Prince, R. L., Smith, M., Dick, I. M., Price, R. I., Webb, P. G., Henderson, K. \& Harris, M. M. (1991). Prevention of postmenopausal osteoporosis: a comparative study of exercise, calcium supplementation and hormone-replacement therapy. New England Journal of Medicine 325, 1189-1195.

Ralston, S. H. (1996). Pathophysiology of osteoporosis. In Osteoporosis. New Perspectives on Prevention and Treatment, pp. 31-40 [J. E. Compston, editor]. London: Royal College of Physicians.

Ramsdale, S. J., Bassey, E. J. \& Pye, D. J. (1994). Dietary calcium intake relates to bone mineral density in premenopausal women. British Journal of Nutrition 71, 77-84.

Recker, R. R., Davies, M. K., Hinders, S. M., Heaney, R. P., Stegman, M. R. \& Kimmel, D. B. (1988). Bone gain in young adult women. Journal of the American Medical Association 268, 403-408.

Reed, J. A., Anderson, J. J. B., Tylavsky, F. A. \& Gallagher, P. N. Jr (1994). Comparative changes in radial-bone density of elderly female lacto-ovo-vegetarians and omnivores. American Joumal of Clinical Nutrition 59, 1197S-1202S.

Reid, I. R., Ames, R. W., Evans, M. C., Gamble, G. D. \& Sharpe, S. J. (1993). Effect of calcium supplementation on bone loss in postmenopausal women. New England Journal of Medicine 328, 460-464.

Reid, I. R., Ames, R. W., Evans, M. C., Gamble, G. D. \& Sharpe, S. J. (1995). Long-term effects of calcium supplementation of bone loss and fractures in postmenopausal women: A randomized controlled trial. American Joumal of Medicine 98, 331-335.

Rico, H., Revilla, M., Villa, L. F., Alvarez de Buergo, M. \& Arribas, I. (1994). Longitudinal study of the effect of calcium pidolate on bone mass in eugonadal women. Calcified Tissue International 54, $477-480$.

Riggs, E. L., Wahner, H. W., Melton, L. J. III, Richelson, L. S., Judd, H. L. \& O'Fallon, W. M. (1987). Dietary calcium intake and rates of bone loss of women. Journal of Clinical Investigations 80, 979-982.

Riis, B., Thomsen, K. \& Christiansen, C. (1987). Does calcium supplementation prevent postmenopausal bone loss? New England Journal of Medicine 316, 173-177.

Sandler, R. B., Slemenda, C. W., LaPorte, R. E., Cauley, J. A., Schramm, M. M., Barresi, M. L. \& Kriska, A. M. (1985). Postmenopausal bone density and milk consumption in childhood and adolescence. American Journal of Clinical Nutrition 42, 270-274.

Sebastian, A., Harris, S. T., Ottaway, J. H., Todd, K. M. \& Morris, R. C. (1994). Improvement of bone mineral balance and skeletal metabolism in postmenopausal women treated with potassium bicarbonate. New England Journal of Medicine 330, 1776-1781. 
Slemenda, C. W., Reister, T. K., Peacock, M. \& Johnston, C. C. (1993). Bone growth in children following cessation of calcium supplementation. Journal of Bone and Mineral Research 8, S154.

Smith E. L., Gilligan, C., Smith, P. E. \& Sempos, C. T. (1989). Calcium supplementation and bone loss in middle-aged women. American Journal of Clinical Nutrition 50, 833-842.

Stevenson, J. C., Whitehead, M. J., Padwick, M., Endacott, J. A., Sutton, C., Banks, L. M., Freemantle, C., Spinks, T. J. \& Hesp, R. (1988). Dietary intake of calcium and postmenopausal bone loss. British Medical Journal 297, 15-17.

Strause, L., Saltman, P., Smith, K. T., Bracker, M. \& Andon, M. B. (1994). Spinal bone loss in postmenopausal women supplemented with calcium and trace minerals. Journal of Nutrition 124, 1060-1064.

Torgerson, D. J., Campbell, M. K., Thomas, R. E. \& Reid, D. M. (1997). Randomised trial of osteoporosis screening: HRT uptake and quality of life results. Archives of Internal Medicine (In the Press).

Tesar, R., Novelovitz, M., Shim, E., Kauwell, G. \& Brown, J. (1992). Axial and peripheral bone density and nutrient intakes of postmenopausal vegetarians and omnivorous women. American Journal of Clinical Nutrition 56, 699-704.

Tylavsky, F. A. \& Anderson, J. J. B. (1988). Dietary factors in bone health of elderly lactovegetarians and omnivorous women. American Journal of Clinical Nutrition 48, 842-849.

Valimaki, M. J., Karkkainen, M., Lamberg-Allardt, C., Laitinen, K., Alhava, E., Heikkinen, J., Impirvaara, O., Makela, P., Palmgren, J., Seppanen, R. \& Vuori, I. (1994). Exercise, smoking and calcium intake during adolescence and early adulthood as determinants of peak bone mass. British Medical Journal 309, 230-235.

Wachman, A. \& Bernstein, D. S. (1968). Diet and osteoporosis. Lancet i, 958-959.

Wickham, C. A. C., Walsh, K., Cooper, C., Barker, D. J. P., Margetts, B. M., Morris, J. \& Bruce, S. A. (1989). Dietary calcium, physical activity, and risk of hip fracture: a prospective study. British Medical Journal 299, 889-891.

Wisker, E., Nagel, R., Tanudjaja, T. K. \& Fledheim, W. (1991). Calcium, magnesium, zinc and iron balances in young women: effects of a low-phytate barley-fibre concentrate. American Journal of Clinical Nutrition 54, $553-559$.

World Health Organization (1994). Assessment of Fracture Risk and its Application to Screening for Postmenopausal Osteoporosis: Report of a WHO Study Group. WHO Technical Report Series no. 843. Geneva: WHO.

Yano, K., Heilbrun, L. K., Wasnich, R. D., Hankin, J. H. \& Vogel, J. M. (1985). The relationship between diet and bone mineral content of multiple skeletal sites in elderly Japanese-American men and women living in Hawaii. American Journal of Clinical Nutrition 42, 877-888. 